\title{
Implementasi Pendidikan Karakter Melalui Budaya Melayu Pada Anak Usia Dini 4-6 Tahun Di Paud Cendana Kecamatan Pantai Labu
}

\author{
Muciani Sulistiwa1, Yusnadi' ${ }^{2}$ Rizka Ramadhana Sembiring ${ }^{3}$, Eviza Husnika \\ 1234 Universitas Negeri Medan \\ Yusnadifip@unimed.ac.id
}

\begin{abstract}
Abstrak
Penelitian ini bertujuan untuk mengetahui implementasi pendidikan karakter melalui budaya melayu pada anak usia dini 4-6 tahun di PAUD Cendana Kec. Pantai Labu. Penelitian ini menggunakan metode kualitatif dan subjek dalam penelitian ini adalah seluruh tutor PAUD Cendana yang berjumlah 5 orang, penulis menjadikan tutor sebagai subjek karena mengingat usia anak yang berumur 4-6 tahun. Data dikumpulkan dengan teknik observasi, wawancara dan dokumentasi. Data yang terkumpul dianalisis dengan langkah reduksi data, display data dan menarik kesimpulan. Hasil penelitian, menunjukkan bahwa kegiatan kelompok belajar di PAUD Cendana kecamatan Pantai Labu baik dari pendidik/tutor maupun peserta didik telah mengimplementasikan pendidikan karakter melalui budaya melayu seperti ; (1) Nilai religius, (2).Jujur, (3).Disiplin, (4).Mandiri, (5).Semangat kebangsaan dan cinta tanah air. Berdasarkan hasil penelitian dapat disimpulkan bahwa implementasi pendidikan karekter melalui budaya melayu di PAUD Cendana Kecamatan Pantai Labu dinyatakan berhasil dalam menerapkan pendidikan karakter melalui budaya melayu.
\end{abstract}

Kata Kunci: Pendidikan karakter, Budaya melayu, Paud

\section{Implementation of Character Education through Malay Culture in Early Childhood 4-6 Years at Paud Cendana, Labu Beach District}

\begin{abstract}
This study aims to determine the implementation of character education through Malay culture in early childhood 4-6 years in PAUD Cendana Kec. Pumpkin Beach. This study used a qualitative method and the subjects in this study were all Cendana PAUD tutors, amounting to 5 people, the authors made the tutors a subject because they remember the age of children aged 4-6 years. Data collected by observation, interview and documentation techniques. The collected data was analyzed by the step of data reduction, data display and drawing conclusions. The results of the study showed that the learning group activities in PAUD Cendana Pantai Labu sub-district both from educators / tutors and students had implemented character education through Malay culture such as; (1) Religious value, (2). Honest, (3). Discipline, (4). Self, (5). Nationalism and love of the motherland. Based on the results of the study it can be concluded that the implementation of character education through Malay culture in Cendana PAUD Pantai Labu Subdistrict was declared successful in applying character education through Malay culture.
\end{abstract}

Keywords: Character education, Malay culture, Paud 


\section{PENDAHULUAN}

Membangun karakter (character building) adalah proses mengukir atau memahat jiwa sedemikian rupa, sehingga berbentuk unik, menarik, dan berbeda atau dapat dibedakan dengan orang lain. Namun membangun karakter bukanlah merupakan produk instant yang dapat langsung dirasakan sesaat setelah pendidikan tersebut diberikan, melainkan merupakan proses panjang yang harus dimulai sejak dini pada anak-anak dan baru akan dirasakan setelah anak-anak tersebut menjadi dewasa. Dalam Undang-undang Sistem Pendidikan Nasional No. 20 tahun 2003 dikenal jalur pendidikan formal, nonformal dan informal. Jalur pendidikan nonformal salah satunya adalah Kelompok Bermain yang merupakan Pendidikan Anak Usia Dini (PAUD).

Peraturan Menteri Pendidikan Nasional (permendiknas) No. 58 tahun 2009 mengatur tentang Standart Pendidikan Anak Usia Dini. Didalamnya menjelaskan tentang standart tingkat pencapaian perkembangan, standart pendidik dan tenaga kependidikan, standart isi, proses dan penilaian yang menjadi salah satu pedoman dalam penyelenggaraan kelompok bermain dalam membangun karakter anak melalui budaya lokal. Untuk penyelenggaraan kelompok bermain dalam membangun karakter anak melalui budaya lokal ini baru difokuskan pada kegiatan PAUD untuk kelompok usia $4-\leq 6$ tahun.

Untuk membangun karakter anak serta mencintai budaya lokal sejak dini maka diperlukan penyelenggaraan Kelompok Bermain yang dapat membangun karakter anak melalui budaya lokal sehingga diharapkan di masa mendatang anakanak Indonesia menjadi anak yang berkualitas dan memiliki karakter yang baik dan dapat diunggulkan sekaligus mencintai budaya bangsanya sehingga mampu menghadapi persaingan yang semakin ketat serta pengaruh negatif dari budaya asing. Anak Indonesia diharapkan tidak hanya memiliki kecerdasan tetapi juga karakter yang baik yang sesuai dengan nilai-nilai budaya bangsa.

Pada

penyelenggaraan kelompok bermain dalam Implementasi Pendidikan Karakter Melalui Budaya Melayu di PAUD Cendana Kec.Pantai Labu ini untuk melengkapi kegiatan pengembangan model PAUD tahun 2010 yang sumber dananya berasal dari Anggaran Biaya Tambahan (ABT) BPPNFI Regional

I. Pengelola/penyelenggara Kelompok Bermain di PAUD Cendana Kec. Pantai Labu, mempelajari model penyelenggaraan Kelompok Bermain dalam menumbuhkan karakter anak melalui budaya melayu. Selanjutnya mereka mengidentifikasi bentukbentuk budaya setempat mengenai makanan, tarian, permainan, tokoh, lagu-lagu yang selanjutnya dijadikan dasar penyusunan kurikulum.

Karakter bangsa sangat tergantung pada kualitas karakter sumber daya manusianya (SDM). Karenanya karakter yang berkualitas perlu dibentuk dan dibina sejak usia dini. Menurut Freud kegagalan penanaman kepribadian yang baik di usia dini akan membentuk pribadi yang bermasalah di masa dewasanya kelak. Kesuksesan orang tua membimbing anaknya dalam mengatasi konflik kepribadian di usia dini ini sangat menentukan kesuksesan anak dalam kehidupan sosial di masa dewasanya kelak ( Muslich, 2011:201).

Implementasi pendidikan karakter melalui budaya melayu pada
Page $\mid 66$ 
anak usia dini 4-6 tahun terdapat nilainilai karakter seperti nilai religius, disiplin, jujur, mandiri semangat kebangsaan dan cinta tanah air. Dimana tujuan penyelenggaraan PAUD dalam membangun pendidikan karakter melalui budaya melayu harus di tanamkan sejak anak usia dini,karena didalam kecerdasan anak berkembang secara optimal dan memperoleh dasar-dasar kearah perkembangan sikap, penegetahuan, keterampilan, dan mengembangkan berbagai potensi anak sejak dini sebagai persiapan untuk hidup, dan menyesuaikan diri dengan lingkungannya termasuk siap memasuki tahap pendidikan berikutnya atau siap memasuki pendidikan dasar. Dan tujuan berikutnya adalah agar anak-anak lebih mengenal dan bangga akan kebudayaan-kebudayaan yang ada, dan mereka tidak akan lupa tradisi-tradisi kebudayaan yang ada di Indonesia.

\section{METODE}

Dalam penelitian ini, peneliti menggunakan jenis penelitian deskriptif kualitatif. Peneliti memilih jenis penelitian deskriptif kualitatif karena penedekatan ini dianggap tepat untuk menggambarkan Implementasi Pendidikan Karakter Melalui Budaya Melayu Pada Anak Usia Dini di PAUD Cendana Kec. Pantai Labu. Subjek dalam penelitian ini adalah seluruh tutor PAUD Cendana yang berjumlah 5 orang, penulis menjadikan tutor sebagai subjek karena mengingat usia anak yang berumur 4-6 tahun.

Dalam jenis penelitian kualitatif, peneliti merupakan instrument utama( Key Instrument). Hakekat peneliti sebagai instrument kunci diaplikasikan dalam teknik pengumpulan data kualitatif menurut Sugiono ( 2008:224) terdiri atas wawancara, observasi dan pengkajian dokumen (dalam bentuk catatan/arsip).

Sebagai keseluruhan, peneliti terjun ke lapangan sebagai instrument utama dalam penelitian ini.Oleh karena Page $\mid 67$ itu, peneliti menggunakan beberapa teknik penumpulan data sebagai berikut; (1) Wawancara, wawancara terhadap informan sebagai sumber data dilakukan dengan tujuan menggali informasi tentang fokus penelitian.Manfaat wawancara ini peneliti dapat menjelaskan atau memparafrasekan pertanyaan yang tidak dimengerti responden, peneliti dapat mengajukan pertanyaan susulan (follow up question), responden cenderung menjawab apabila diberi pertanyaan, dan responden dapat menceritakan sesuatu yang terjadi pada masa silam, (2) Observasi atau pengamatan merupakan alat penilaian banyak digunakan untuk mengukur tingkah laku individu ataupun proses terjadinya suatu kegiatan yang dapat diamati, baik dalam situasi yang sebenarnya maupun dalam situasi buatan, (3) Teknik pengumpulan data melalui studi dokumentasi digunakan untuk melengkapi data dan informasi yang diperoleh dari dua teknik terdahulu.Tujuan studi dokumentasi ini adalah mempelajari seluruh dokumen yang berkaitan dengan implementasi pendidikan karakter melalui budaya melayu. Dengan teknik ini diharapkan akan diperoleh data seperti dokumen, foto, profil sekolah, dan lain-lain.

Kegiatan teknik analisis data dilakukan secara berkesinambungan dari awal sampai akhir penelitian, di lapangan dan di luar lapangan. Dalam hal ini diunakan teknik analisis data yang dikemukakan Sugiyono (2008 : 247) yakni reduksi data, penyajian data, dan kesimpulan. 


\section{PEMBAHASAN}

Berdasarkan hasil wawancara dan observasi yang dilakukan dapat dilihat bahwa tujuan dari pendidikan karakter melalui budaya melayu adalah untuk mempertahankan nilai-nilai dari kebudayaan melayu supaya tidak hilang. Maka pendidik mengupayakan untuk memperkenalkan kembali berbagai permainan tradisional, makanan tradisional, pakaian tradisional, adat-istiadat, alat transportasi. Metode yang digunakan tutor dalam implementasi pendidikan karakter adalah melalui pendekatan kepada anak-anak, agar anak-anak tidak takut kepada tutor dan senantiasa berani mengungkapkan pendapatnya. Anak--anak sangat antusias dalam mengikuti kegiatan belajar seperti kegiatan bernyanyi, bermain, dan mendengarkan cerita daerah melayu.

Dalam proses kelompok bermain di PAUD Cendana diawali dengan kegiatan orientasi dan sosialisasi kepada orang tua peserta didik oleh pengelola untuk mendiskusikan peran sekolah dan peran orang tua dalam mendukung program dalam membangun karakter melalui budaya melayu. Proses pembelajaran dikelompok bermain dilakukan oleh pendidik sesuai dengan program pembelajaran dengan menggunakan standart perkembangan anak sebagai pegangan dasar. Pembelajaran dilakukan dengan menggunakan metode "belajar melalui bermain" dengan pendekatan tematik yang berhubungan dengan penyelenggaraan kelompok bermain dalam membangun karakter anak melalui budaya melayu. Berikut ini penjelasan tutor (1) dalam wawancara sebagai berikut :
"Untuk memperkenalkan pendidikan karakter melalui budaya melayu kami dari pihak penyelenggara mengadakan pendekatan dan kerja sama kepada orang tua dengan cara mempertemukan pihak penyelenggara Page | 68 dengan orang tua pada rapat di sekolah, yang membahas tentang pentingnya pendidikan karakter melalui budaya melayu pada anak usia dini yang bertujuan untuk menumbuh kembangkan nilai-nilai karakter pada anak melalui kebudayaan melayu, agar kebudayaan melayu tidak terlupakan".

Jadi dari deskripsi data di atas pembelajaran dilakukan dengan menggunakan metode pendekatan kepada orang tua. Selanjutnya untuk keterpaduan penyelenggaraan dilakukan pertemuan orang tua dengan penyelenggara kelompok bermain, pendidik, dinas/instansi terkait secara periodik sesuai dengan periodik sesuai dengan program pembelajaran yang telah disusun dalam menumbuhkan karakter religius, jujur, dispilin, mandiri, semangat kebangsaan dan cinta tanah air. Pelaksanaan kegiatan dapat dilakukan dengan persiapan setting ruangan dan juga bahan-bahan yang diperlukan dalam proses kegiatan yang memanfaatkan budaya lokal. Dalam pelaksanaannya juga dengan strategi dengan membangun komitmen antara orang tua, penyelenggara, pengelola, pendidik kelompok bermain serta dinas/instansi terkait. Kepada pendidik diberikan pemahaman untuk dapat melakukan persiapan kegiatan pembelajaran dikelompok sesuai dengan kurikulum yang telah disusun dan kepada orangtua diberikan pemahaman setiap kegiatan yang dilakukan oleh anak di kelompok bermain sesuai dengan tema yang telah ditetapkan sehingga dapat ditindak lanjuti di dalam keluarga. 
Selanjutnya kegiatan yang dilaksanakan oleh dinas/instansi terkait dengan peserta didik didampingi oleh orang tua, pendidik sesuai dengan program pembelajaran yang telah disusun dalam menumbuhkan karakter. Nilai-nilai karakter yang akan dibangun beserta proses kegiatan mengacu pada kurikulum dan bahan ajar yang telah disiapkan.

Materi dan kurikulum dalam penyelenggaraan kelompok bermain dalam membangun karakter anak usia dini melalui budaya melayu meliputi 5 (lima) aspek perkembangan yaitu nilainilai agama dan moral, fisik, kognitif, bahasa, sosial emosional yang dikaitkan dengan membangun karakter religious, jujur, disiplin, mandiri serta semangat kebangsaan dan cinta tanah air melalui budaya melayu. Materi mengacu kepada budaya melayu sedangkan kurikulum disusun berdasarkan acuan Peraturan Menteri Pendidikan Nasional No. 58 tahun 2009 tentang standar perkembangan anak usia dini.

Evaluasi dalam penyelenggaraan kelompok bermain di PAUD Cendana dalam membangun karakter anak melalui budaya melayu meliputi

\section{Evaluasi terhadap peserta didik}

Evaluasi ini dilakukan untuk menilai tingkat perkembangan peserta didik yang dapat dilakukan melalui :

a. Pemantauan selama proses pembelajaran berlangsung.

b. Penilaian terhadap sikap dan perilaku peserta didik ketika proses pembelajaran berlangsung untuk mengetahui apakah karakter anak sudah terbangun.

\section{Evaluasi terhadap pendidik}

Evaluasi dilakukan untuk
mengetahui tingkat kesesuaian
program belajar dengan tujuan
penyelenggaraan program serta
keefektifan dalam memfasilitasi
peserta didik.

Page $\mid 69$

\section{Evaluasi terhadap penyelenggaraan program}

Evaluasi ini ditujukan untuk menghimpun data dan informasi tentang berbagai aspek yang berkaitan dengan penyelenggaraan program.Evaluasi ini penting dilakukan untuk memperoleh masukan yang bermanfaat bagi perbaikan pelaksanaan kegiatan dimasa mendatang. Berikut ini hasil wawancara dan obeservasi pada tutor (5) mengenai evaluasi pembelajaran kelompok belajar sebagai berikut :

"Dalam pengevaluasian pada kelompok belajar di PAUD Cendana ini bertujuan untuk melihat sampai sejauh mana perkembangan peserta didik dalam kegiatan belajar melalui bermain. Untuk itu kami para tutor harus mempersiapkan berbagai bentuk catatan seperti pengamatan harian guru, catatan yang objektif dan akurat memuat fakta tentang apa yang dilihat dan didengar, dan catatan kusus (anekdot)".

Sesuai dengan data di atas, peneliti menyimpulkan evaluasi merupakan komponen penting dan bagian terpadu dari sebuah rangkaian proses pembelajaran. Rangkaian ini diawali dengan kegiatan perencanaan, pengelolaan, serta evaluasi terhadap keseluruhan rangkaian proses pembelajaran yang telah dilaksanakan. Kegiatan evaluasi ini sangat membantu dalam memberikan gambaran terhadap pencapaian perkembangan anak. Evaluasi dilakukan pada saat 
anak masuk ke lembaga PAUD, selama proses pembelajaran, dan hasil pembelajaran.

Dari hasil penelitian di PAUD Cendana Kecamatan Pantai Labu terlihat bahwa pengelola kelompok bermain mempelajari model penyelenggaraan kelompok bermain dalam menumbuhkan karakter anak melalui budaya melayu.Selanjutnya mereka mengidentifikasi bentukbentuk budaya melayu mengenai makanan, tarian, permainan, tokoh, lagu-lagu yang selanjutnya dijadikan dasar penyusunan kurikulum.

Penyelenggaraan kelompok bermain di PAUD Cendana Kecamatan Pantai Labu diawali dengan kegiatan orientasi dan sosialisasi kepada orang tua peserta didik oleh pengelola untuk mendiskusikan peran sekolah dan peran orangtua dalam mendukung program dalam membangun karakter melalui budaya melayu. Proses pembelajaran di kelompok bermain Cendana dilakukan oleh pendidik sesuai dengan program pembelajaran dengan menggunakan standart perkembangan anak sebagai pegangan dasar. Pembelajaran dilakukan dengan menggunakan metode "belajar melalui bermain" dengan pendekatan tematik yang berhubungan dengan penyelenggaraan kelompok bermain dalam membangun karakter anak melalui budaya melayu. Selanjutnya untuk keterpaduan penyelenggaraan dilakukan pertemuan orang tua dengan penyelenggara kelompok bermain, pendidik, dinas/instansi terkait secara periodik sesuai dengan program pembelajaran yang telah disusun dalam menumbuhkan karakter religius, jujur, disiplin, mandiri, semangat kebangsaan dan cinta tanah air. Pelaksanaan kegiatan dapat dilakukan dengan persiapan setting ruangan dan juga bahan-bahan yang diperlukan dalam proses kegiatan yang memanfaatkan budaya melayu. Dalam pelaksanaannya juga dengan strategi membangun kotmitmen antara orang Page $\mid 70$ tua, penyelenggara, pengelola, pendidik kelompok bermain serta dinas/instansi terkait.

Kepada pendidik diberikan pemahaman untuk dapat melakukan persiapan kegiatan pembelajaran dikelompok sesuai dengan kurikulum yang telah disusun dan kepada orang tua diberikan pemahaman setiap kegiatan yang dilakukan oleh anak dikelompok bermain sesuai dengan tema yang telah ditetapkan sehingga dapat ditindak lanjuti di dalam keluarga. Nilai-nilai karakter yang akan dibangun beserta proses kegiatan mengacu pada kurikulum dan bahan ajar yang telah disiapkan.

Hasil dari penyelenggaraan kelompok bermain melalui budaya melayu di PAUD Cendana Kecamatan Pantai Labu dalam membangun karakter anak adalah tumbuh kembangnya jiwa peserta didik pada kelompok bermain yang terlihat dalam nilai-nilai pendidikan karakter seperti; (1). Nilai religius, dilaksanakan dengan cara; Berdoa sebelum dan sesudah belajar, memberi dan membalas salam, mengenal dan menyayangi ciptaan Tuhan, berpakaian sopan, rapid an bersih. (2). Nilai jujur,dilaksanakan dengan cara; Melakukan kegiatan permainan sesuai dengan aturan, mengembalikan alat/bahan main. (3). Nilai disiplin, dilaksanakan dengan cara; Datang ke sekolah tepat waktu, mengikuti aturan kegiatan main, berbaris sebelum masuk ke dalam 
kelas. (4). Nilai mandiri, dilaksanakan dengan cara; Melakukan makan minum dan berpakaian sendiri, toilet training (BAB dan BAK), merapikan alat/bahan belajar dan main. (5). Nilai semangat kebangsaan dan cinta tanah air, dilaksanakan dengan cara; melaksanakan upacara bendera setiap hari senin, menyanyikan lagu-lagu kebangsaan dan lagu wajib, menyanyikan lagu-lagu daerah, memperingati hari-hari besar nasional.

\section{KESIMPULAN}

Implementasi pendidikan karekter melalui budaya melayu di PAUD Cendana Kecamatan Pantai Labu dinyatakan berhasil dalam kegiatan kelompok belajarnya, baik dipandang dari segi religius, jujur, disiplin, mandiri serta semangat dan cinta tanah air. Penyelenggara kelompok bermain mempelajari model pelaksanaan kelompok bermain dalam menumbuhkan karakter anak melalui budaya melayu.Selanjutnya diidentifikasi bentuk-bentuk budaya melayu mengenai makanan, terian, permainan, tokoh, lagu-lagu yang selanjutnya dijadikan dasar penyusunan kurikulum. Berdasarkan pelaksanaan kegiatan kelompok belajar dapat dilakukan dengan persiapan setting ruangan dan juga bahan-bahan yang diperlukan dalam proses kegiatan yang memanfaatkan budaya melayu. Dalam pelaksanaannya juga terdapat strategi membangun kotmitmen antara orangtua, penyelenggara, pengelola, pendidik kelompok bermain serta dinas/instansi terkait.Kepada pendidik diberikan pemahaman untuk dapat melakukan persiapan kegiatan pembelajaran di kelompok sesuai dengan kurikulum yang telah disusun dan kepada orang tua diberikan pemahaman setiap kegiatan yang dilakukan oleh anak dikelompok bermain sesuai dengan tema yang telah ditetapkan sehingga dapat ditindak lanjuti di dalam keluarga.

Page $\mid 71$

\section{DAFTAR PUSTAKA}

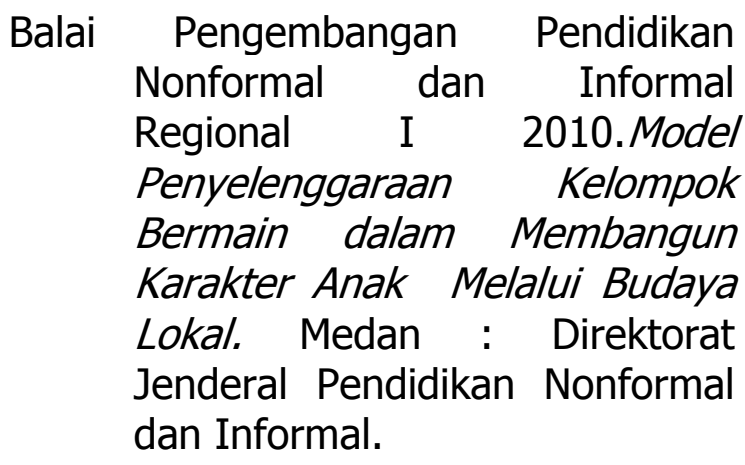

Depdiknas. 2003. Undang-undang Republik Indonesia No.20 Tentang Sistem Pendidikan Nasional. Jakarta : Madya Duta.

Hadiyati, N. 2011. Kebudayaan Melayu dalam

(http://pointofauthorities.blogsp ot.Com/2011/11/Kebudayaanmelayu.html, diakses 14 November 2011).

Gutami. 2010. Pendidikan Karakter pada PAUD, dalam (http: // www.pendidikan

Karakter.pdf, diakses 20 November 2011).

Koentjaraningrat. 1976. Manusia dan Kebudayaan di Indonesia. Jakarta : Djambatan.

Koesoema A, Doni. 2007. Pendidikan Karakter :Strategi Mendidik Anak di Zaman Modern. Jakarta : Grasindo

Kahl, J.A. 1968. The Measurement of Modernism.A Study of Values in 
Brasil and Mexico, Austin, University of Texas Press.

Megawangi, Ratna. 2008.

Pengembangan Program

Pendidikan Karakter Di

Sekolah: Pengalaman Sekolah

Karakter dalam

(http://pustaka.ut.ac.id/Pdfartik

el/TIG101.pdf, diakses 20 Julu

2011 Pukul 11.20 WIB).

Muslich, Masnur. 2011. Pendidikan Karakter (Menjawab

Tantangan Krisis

Multidimensional). Jakarta :

Bumi Aksara.

Narwanti, Sri. 2011. Pendidikan Karakter (Integrasian 18 nilai Pembentuk karakter dalam Mata Pelajaran). Yogyakarta : Familia (Grup Relasi Inti Media).

Pusat Kurikulum. 2009. Pengembangan Pendidikan Budaya dan Karakter Bangsa.Yogyakarta : Pedoman Sekolah

Prayitno, dkk. 2010. Pendidikan Karakter Dalam Pembangunan Bangsa. Jakarta: Pascasarjana Universitas Negeri Medan.

Santoso, Soegeng. 2009. Dasar-dasar Pendidikan TK. Jakarta : Universitas Terbuka.

Simanjuntak, Bungaran. A.2010. Melayu Pesisir dan Batak Pegunungan (Orientasi Nilai Budaya).Jakarta : Yayasan Obor Indonesia.

Sugiono. 2008. Metode Penelitian Kuantitatif, Kualitatif dan $R \& D$. Bandung : Alfabeta. 